\title{
A fábrica-mãe: cotidiano fabril e a construção da memória dos operários da Willys Overland de Jaboatão
}

\author{
Karlene Araújo*
}

\section{Breves Considerações}

No dia 14 de julho de 1966, no município de Jaboatão, em Pernambuco, foi inaugurada a fábrica de automóveis Willys Overland do Brasil. Construída em uma regiáo marcada historicamente pelas greves e reivindicaçóes dos trabalhadores rurais e pela presença e atuação dos comunistas. Tornando-se, assim, conhecida como Moscouzinho (Silva, 2017). A Willys se posicionava como ponto de inflexáo para o cenário de acusaçóes e lutas sociais e se apresentava como a redenção social, econômica e de trabalho para os seus operários. Os dirigentes da fábrica mobilizavam a ideia de uma "revolução da paz", um discurso que estava em sintonia com os anúncios e propagandas do governo militar para a regiáo Nordeste do país. Em Jaboatão, a fábrica mobilizou discursos de modernização e de progresso, que procuraram produzir sentido para sua instalaçáo e construíram o agenciamento de novos disciplinamentos para trabalhadores rurais transformados em operários urbanos. Marcando posicionamento e destacando a sintonia com o governo ditatorial, a Willys tentou construir uma identidade para os seus operários que passaram a ser chamados e reconhecidos como "trabalhadores da Willys". A estratégia apontava para o abandono das atividades sindicais dos operários,

Doutora em História pela Universidade Federal de Pernambuco (UFPE). Integrante da Equipe Técnica do Laboratório História e Memória da UFPE/TRT 6a Região (LAHM). Tem como área de interesse os estudos sobre Trabalho e Trabalhadores no período de Ditadura Militar no Brasil. E-mail: karlenesayanne@gmail.com. 
classificadas como subversivas. O que indicaria para uma descaracterização desse operário enquanto ser político. Para os seus operários, segundo relatos de memória, a Willys era uma fábrica-mãe, que acolhia e dava assistência aos seus trabalhadores.

\section{Cotidiano fabril}

"Eu fiquei sozinho aqui, fui passando de uma [fábrica] para outra", assim rememora Antonio Justolino Barbosa (2018), que começou a executar o trabalho de montar carro em Pernambuco no ano de 1969. Tinha vinte e cinco anos de idade quando foi admitido na Willys. Até então nunca tinha visto ninguém montar um automóvel. $\mathrm{O}$ primeiro dia de trabalho foi em 28 de maio. Com a carteira profissional assinada, Antonio iniciava sua relação trabalhista com a Willys. Depois seguiu trabalhando para a Ford. Antonio continua trabalhando no mesmo prédio construído na década de 1960 . Hoje, aos 75 anos de idade, segue no setor de montagem, mas agora do componente automotivo chicote elétrico, que é instalado no carro JEEP, produzido na cidade de Goiana (PE). Entre histórias contadas pelo operário, destacaram-se aquelas enaltecedoras da Willys e da Ford -Willys presentes em suas memórias (Antônio Justino Barbosa, 2018).

Natural de Surubim, cidade localizada a $120 \mathrm{~km}$ de Recife, Antonio é filho de trabalhadores rurais. O primeiro emprego que conseguiu na região metropolitana do Recife foi em uma granja, em Jaboatáo. Sua função era vender galinhas. Nesse emprego conseguiu uma indicação para o trabalho na fábrica. Foi Flérida Cortizo, a funcionária do setor administrativo da Willys, umas de nossas entrevistas, que o recomendou para o novo trabalho. Na fábrica, ele foi soldador, lanterneiro, desamassava e retirava qualquer defeito que o carro pudesse ter. O operário começava uma jornada de trabalho muito diferente do que estava acostumado. Seria a oportunidade de melhores condiçóes de vida e salário.

Antonio Justolino contou que chegava cedo ao trabalho. Segundo relatos, às sete horas da manhã os operários estavam em seus postos para o início de mais um dia de trabalho. Antonio rememorou a montagem dos carros que era toda manual,

[...] as peças, o capô vinha uma chapa pronta, aqui eram colocados os reforços nos capôs, os para-lamas vinham só as peças e eram colocados aqui, a buzina era montado aqui, nós tínhamos a prensa para fazer tudo isso, os para-lamas tinham os gabaritos direito ou esquerdo, colocávamos os dois, na época que fui para São Paulo era um robô, mas aqui era na base da máquina, a máquina 
tinha uma mangueira que entrava água, quando se abria aquela água jogava dentro, porque se não esfriasse ele derretia, ponteava até que deixavam o para-lama pronto, aquele para-lama ali já estava pronto para colocar no carro e tinha outro setor de preparar cabine do carro, a porta colocava depois, peça por peça, menos o chicote, o chicote vinha de São Paulo. O chassi vinha de São Paulo, aqui tinha uma linha que colocávamos o chassi, colocávamos bateria, volante, tudo, quando a cabine vinha, entrava no fosfato, depois do fosfato, entrava na cabine de pintura, recebia toda uma pintura, tirar toda a impureza daquela peça, depois entrava numa estufa quente para receber a primeira pintura, passava por uma lixa de água para depois entrar em uma outra cabine só de ar, para tirar toda poeira, para depois sair para a pintura final, voltava dentro dos trilhos, aquele carrinho, era pintado, colocava farol, o chicote, colocávamos a porta. As portas vinham da funilaria, outra linha, depois da funilaria, tinha a instalação onde já pegava a carroceria, os pneus e os bancos, tudo aqui. (Antonio Justolino Barbosa, 2018).

Essa fala de Antonio Justolino é carregada de signos e comparações. O operário construiu quase uma atmosfera lúdica para dizer que o trabalho desenvolvido pelos operários de Jaboatáo era todo manual. Parafuso por parafuso. Ao passo que os operários da fábrica de São Paulo ${ }^{1}$ trabalhavam em um ambiente robotizado. A riqueza de detalhes presentes na fabricação de um carro, a partir dos relatos de Antonio, faz-nos questionar que tipo de fábrica moderna foi instalada pela Willys em Jaboatão. Os discursos sobre o moderno pareciam ser diferentes. De um lado tínhamos uma fábrica na qual o seu operário precisava instalar peça por peça - porta, tintura, tapeçaria -, do outro lado nos apresentava uma fábrica que já operava com robôs. A propaganda da Willys apresentava uma modernização que deixava pressupor um processo tecnológico. Mas Antonio relata um trabalho manual, quase artesanal. Havia poucas máquinas, diferente da fábrica de São Paulo.

Antonio trabalhou em vários setores da linha montagem. Ao contar sobre o seu dia de trabalho, parecia ter todas as etapas da montagem dos automóveis em sua mente. Náo se tornou, pela sua narrativa de memória, um especialista em apenas uma etapa do trabalho. $\mathrm{O}$ seu relato proporciona imaginar a transformação de uma chapa de ferro em um objeto de consumo. Faz pensar que ele se tornou um homem-fábrica, passando de uma fábrica a outra, Willys-Ford-TCA-FCA, assim como os carros em uma linha de montagem.

1 Referência à fábrica Willys Overland de São Bernardo do Campo (SP). 
O trabalho na fábrica começava às sete horas da manhã e terminava às cinco horas da tarde, de segunda a sexta-feira. Nos sábados não havia expediente. $\mathrm{O}$ horário de almoço para todos os operários, segundo memórias de Antonio Justino, era às onze horas da manhã. A produção diária era de 35 carros. No final do dia de trabalho, esses carros deviam sair prontos da linha de montagem. Para isso, outros 35 carros iam para a funilaria. Estes ficavam para o trabalho do dia seguinte. As rememoraçóes de Antonio diziam ainda da presença dos equipamentos de segurança usados pelos operários. Lembrou dos macacóes, das luvas, dos óculos, das máscaras e dos aventais usados no cotidiano da fábrica.

Antonio Justolino citou informaçôes que serão importantes para o desenrolar dessa história. São memórias que indicam açóes, práticas e discursos construídos no local de trabalho. Dados que nos possibilitam analisar a construção da ideia da fábrica Willys como uma mãe para os seus operários, a partir dos seus relatos de memória. Nesse sentido, a historiadora Regina Guimarães diz que

[...] muitas vezes, meras lembranças, reminiscências, que emergem como sinais involuntários - fiapos desgarrados -, mas fundamentalmente plenos em revelaçôes. A riqueza está em poder apreender nas histórias narradas os fios de tensôes, as linhas contraditórias, talvez muito mais ambíguas, linhas de fuga que formam um quadro complexo e desafiador para a pesquisa histórica. (Guimarães Neto, 2006, p. 56).

Interessam, nos relatos de memória, as histórias contadas, construídas. As histórias que sobreviveram à passagem do tempo. Mas também os fios, aparentemente soltos, os lampejos da memória, os rastros que as histórias não contadas deixam pelo caminho.

Assim, as memórias dos operários e trabalhadores do setor administrativo são estudadas e analisadas como documentos que contam uma história de um passado recente por um testemunho situado em configuraçóes históricas diferentes. Como outras fontes utilizadas no fazer historiográfico, os relatos orais não dispensam avaliações críticas. Para Regina Guimarães, "as recordações não são meras exposiçóes da memória, mas um olhar que atravessa o tempo múltiplo, um olhar que constrói, decifra, revela e permite a passagem de um tempo a outro" (Guimarães Neto, 2006, p. 56).

Antonio Justolino lembrou que o seu contrato de trabalho com a fábrica começou quando era Willys-Ford, mas que na prática ainda era chamada apenas de Willys. ${ }^{2}$ Ao voltar no tempo e tentar construir uma narrativa para os

$2 \quad$ A venda ocorreu em 1967. 
primeiros anos de trabalho na fábrica, disse que havia em torno de 250 operários diariamente na fabricação dos carros. Outros documentos indicam que no início das atividades foram empregados cerca de 400 trabalhadores diretos.

"Mais de 100 pessoas batem à porta da Willys por dia. E muitos só levam a carteira de trabalho e uma imensa vontade de trabalhar. Não leem, não escrevem o nome, nunca viram uma empilhadeira. Vêm de longe, atraídos pela notícia de trabalho" (Vem..., 1966, p. 47). Assim, a imprensa registrava a procura por emprego na Willys nos primeiros meses do ano de 1966. Empregos diretos e indiretos começaram a ser oferecidos desde a obra de construção das instalações da fábrica, entre 1965 e 1966.

\section{A fábrica-mãe}

As entrevistas realizadas permitem identificar a produção de uma memória positiva sobre o trabalho na Willys. ${ }^{3}$ São relatos que delineiam a imagem de uma fábrica-mãe, que acolhia e dava assistência. Para os atores sociais entrevistados, na fábrica se tornou uma verdadeira família entre os diretores da Willys e seus operários. Falaram dos bons salários recebidos, das festas, do restaurante. Essa é uma memória produzida sobre o trabalho fabril na Willys, 54 anos depois de sua inauguração.

Essa imagem, de uma boa fábrica para os operários, também foi veiculada nos jornais. As propagandas da Willys diziam do pagamento de bons salários, das boas condiçôes de trabalho, do acesso à saúde e à educação para os filhos dos empregados. Os dirigentes da fábrica, segundo a imprensa e a análise dos relatos orais, teriam criado um envolvimento afetivo da Willys com os seus operários e os seus clientes - para quem as propagandas tanto de jornais quanto televisivas eram direcionadas.

Parte dos trabalhadores morava em Jaboatão e Cabo de Santo Agostinho, nas proximidades da fábrica. Muitos operários moravam na área urbana. Uma região que passou a empregar mão de obra, até entáo, não qualificada para o trabalho fabril. Um emprego que teria possibilitado a Paulo Feliciano, ${ }^{4}$ por exemplo, morar na praia de Candeias, juntamente com toda sua família. A nova

Entrevistadas e entrevistados: Flérida Cortizo, que trabalhou na parte administrativa da fábrica; Mathias Filho, que trabalhou na área de vendas; Aparecida, que trabalhou na parte de finanças, já na fábrica Ford; Luís Regueira, que trabalhou na parte administrativa; Antonio Justolino que foi montador de carro; Arhtur Sentieiro, responsável por formar a mão de obra.

4 Começou a trabalhar na construção da fábrica e foi demitido em 1967. 
moradia do operário e da sua família foi noticiada em reportagem na Revista Quatro Rodas. Na matéria da revista, foi a Willys que proporcionou melhores condições de vida para eles.

Os operários da Willys contaram que se sentiam pertencentes à "família Willys". Eram os jogos de futebol, as festas de final de ano, a distribuição de material escolar para as crianças. Foram criadas formas de pertencimento à fábrica. A busca por criar vínculo com os operários não era uma estratégia particular da Willys. Antonio Montenegro afirma que objetivo parecido tinha sido adotado por outra fábrica norte-americana de automóveis, a Studebaker. Para essa fábrica eram contratados preferencialmente membros da mesma família e se pagava bons salários como estratégia de criar o compromisso dos operários com o trabalho, em razão das péssimas condições de trabalho e exploração que se vivia no cotidiano fabril. Essa ação da empresa criava uma atmosfera de bem estar entre os operários, apesar da jornada extenuante que desenvolviam. Um operário contou a Montenegro que "[...] todos estavam como em casa. Todos eram amigos e tentavam se dar bem. [...] todos eram táo amigos. Todos gostavam de trabalhar na Studebaker. Talvez porque fosse o melhor emprego que se podia encontrar, entende"; para outro operário, identificado como M., na fábrica "[...] era como trabalhar em família. Era mesmo" (Montenegro, 1994, p. 25).

$\mathrm{Na}$ linha de montagem da Willys de Jaboatão trabalhavam apenas homens. As mulheres desenvolviam atividades no setor administrativo. ${ }^{5}$ Flérida Cortizo, uma de nossas entrevistadas, foi admitida em 1966, a poucos dias da inauguração da Willys. Antes era empregada na Varig, uma companhia aérea. Flérida disse que foi convidada a trabalhar na Willys e seduzida pelo discurso de que a empresa pagava o maior salário no estado de Pernambuco (Flérida Cortizo Pozzas, 2016).

Nascida em dezembro de 1936, filha de pai espanhol e mãe brasileira, Flérida contou que até os sete, oito anos de idade viveu em Recife. Nesse período da vida, estudou no Colégio São José, localizado no bairro da Boa Vista. Depois a família se mudou para o engenho Catanduba. O pai, Benigno Cortizo Pozzas, havia comprado a propriedade localizada em Jaboatáo. Nessa nova fase da vida passou a ter aulas particulares em casa com uma professora. Ela se recorda que morou poucos anos no engenho e logo a família passou a residir no centro da cidade. As memórias falam das vivências e das experiências que teve ao longo de sua adolescência morando em Jaboatão. Contou-nos também sobre as idas ao cinema Samuel Campelo.

5 Encontrei o registro de trabalho de outras quatro mulheres, nos processos trabalhistas 07/68, 1462/69, 1034/69 e 33/70 da Junta de Conciliação e Julgamento de Jaboatão no acervo do Laboratório História e Memória da UFPE e TRT 6a região (LAHM). 
Como consta em sua carteira profissional, Flérida começou a trabalhar na Willys no dia 1 de julho de 1966. Tinha 29 anos de idade. Ocupava um cargo no setor administrativo da fábrica, tendo contato direto com os diretores. Ela foi admitida para desenvolver serviços gerais - como auxiliar administrativa-, atendendo as demandas de toda a gerência. Permaneceu na fábrica mesmo após a venda para a Ford, em 1967. Sob a nova administração, Flérida passou a ocupar o cargo de Chefe de Compras. Tornou-se a responsável pela aquisição de materiais não produtivos para a fábrica.

No jornal Notícias Ford, publicado pela empresa, Flérida foi descrita como proprietária de uma conversa fluente, "uma fonte inesgotável de assuntos, talvez por causa de sua vivência, sempre envolvendo muitas viagens, pelo Brasil e exterior, e um amplo conhecimento das coisas do Recife e do Nordeste" (Flérida: ..., 1975). ${ }^{6}$ A matéria do jornal destacou a eficiência com a qual desenvolvia o seu trabalho. Notícias Ford ressaltou como a menina que cresceu em engenho se tornou a primeira e única mulher responsável pelas compras (de materiais em grande volume) da primeira fábrica de carros do Nordeste (Flérida: ..., 1975; As sete..., 1972). ${ }^{7}$ Em dezembro de 1991, recebeu uma homenagem da empresa em comemoraçáo aos 25 anos de serviço prestado - o papel timbrado do certificado da homenagem é da Autolatina. ${ }^{8}$ Foi aposentada como funcionária da Ford em 1993.

A Willys apostou no registro e na projeção da imagem de um operário feliz, grato pelo emprego, empenhado e que pouco (ou nada) reclamava. Essa imagem foi apropriada pelas empresas que assumiram o controle acionário da fábrica ao longo dos anos (Willys- Ford, Autolatina, TCA, FCA). Essa afirmativa é formulada a partir da leitura de documentos e da visita feita por esta pesquisadora à fábrica, hoje propriedade da Fiat Chrysler Automobiles. Na ocasiáo, fui recebida pelo diretor de relaçóes trabalhistas. Em passeio guiado pelas instalaçóes, o diretor registrou que ainda seguiam os modelos propostos pela Willys. Todos os "trabalhadores" usavam o mesmo uniforme. Do zelador, do operário até os diretores, todos usavam a mesma roupa. Sem distinção de cargos. Todos almoçavam no mesmo restaurante - inaugurado no período da Willys. Para o diretor, aquela era uma maneira da empresa mostrar ao "trabalhador" que fazia parte de uma família. $\mathrm{O}$ trabalhador aparece nesse momento da narrativa

6 FLÉRIDA: A menina de engenho que virou uma compradora. Notícias Ford, jan. 75. Acervo pessoal de Flérida Cortizo.

AS SETE garotas de Pernambuco. Notícias Ford, jan. 72. Acervo pessoal de Flérida Cortizo.

A empresa Autolatina foi a fusão entre Ford e a Volkswagen. A parceria foi encerrada em 1996. HOMENAGEM POR TEMPO DE SERVIÇO. Autolatina: Dezembro de 1991. Acervo pessoal de Flérida Cortizo. 
entre aspas porque, assim como nos documentos sobre a Willys, o diretor de relações trabalhistas não usa o termo operário, gerente ou zelador para se referir as pessoas que trabalham na fábrica. Usa-se "trabalhadores". O termo engloba todos e todas que trabalham na empresa.

Localizamos no jornal Notícia Ford, uma matéria com o título Jaboatão decidiu: é o "operário padrão". A matéria se referia ao concurso nacional promovido pelo Serviço Nacional de Aprendizagem Industrial (SENAI). João Vicente, 37 anos, horista, admitido na fábrica como servente de manutenção, promovido a supridor na aérea de controle de material, foi eleito pelos próprios operários como representante no concurso. Ganhou também uma competição estadual para concorrer como modelo de operário no concurso nacional. Com esta açáo, o SENAI visava "premiar o esforço e a dedicação do operário em sua função profissional, além de sua integração como elemento humano no ambiente de trabalho" (Jaboatão..., 1972). ${ }^{9}$ Esse é um dos poucos documentos no qual se registrou uma referência ao termo "operário" da fábrica. As características de operário modelo foram registradas no jornal: "afeito as coisas simples da vida - sua maior alegria é passar horas de folga com a família e pescar 'quando dá na telha' - João Vicente é considerado o tipo de boa gente entre o pessoal da fábrica". O operário disse: "gosto de fazer amigos e procuro nunca fazer mal a ninguém" (Jaboatão..., 1972). Encontramos nesse registro o que poderíamos considerar de modelo, ou linhas gerais de uma cartilha do operário da Willys. Uma pessoa ligada à família, aos amigos, tranquilo e que se destacava pelo serviço desenvolvido no trabalho.

Parte dos documentos estudados apontou para a construção da ideia desse operário feliz, que não precisava reclamar nem do trabalho desenvolvido, nem da fábrica e nem mesmo dos seus direitos trabalhistas. Entretanto, um conjunto de processos da Justiça do Trabalho possibilita outras leituras. Os operários faziam suas reivindicaçóes e, em alguns casos, levaram-nas até a Justiça do Trabalho.

Não foi possível localizar registros de reclamaçóes das condições de trabalho fora do espaço jurídico. Prevaleceu a construção da ideia da fábrica-mãe. $\mathrm{O}$ emprego na Willys de Jaboatáo foi apresentado, de um lado, como a oportunidade de produzir um dos símbolos de modernização e paixão do brasileiro - o carro. De outro, existia a questão de, em parte, os operários terem saído do árduo trabalho rural e incorporados, ensinados e disciplinados ao trabalho fabril. Era a construção da ideia de um "novo trabalhador" - operário, suplantando a imagem do trabalhador rural pobre, maltrapilho, sem instrução e que vivia em míseras condições de vida e de trabalho. 
Ao analisar essas construçóes imagéticas e discursivas entendemos que os operários da Willys passaram por transformaçóes. Ao participarem de reportagens em jornais, por exemplo, davam sinais dessas mudanças. $O$ corpo falava, expressava. Experiências, vivências, sociabilidades escrevem ao longo da vida das pessoas marcas nos seus corpos. Para os operários da Willys, os seus corpos passaram a ser alvo de outras escritas a partir da admissão no novo trabalho. Escritas relacionadas a todas as transformaçóes sociais, econômicas, culturais e de trabalho pelas quais passaram. Apontavam para as novas formas de se colocar no mundo do trabalho ao qual pertenciam.

\section{Os operários}

Sobre o emprego na fábrica, um primeiro ponto a ser observado é quanto ao contrato da mão de obra. $\mathrm{Na}$ Willys observamos dois setores de funcionamento da fábrica: o setor administrativo e a linha de montagem. A parte administrativa contava com o trabalho de um grupo maior, oriundo da fábrica de São Bernardo do Campo (SP) e um grupo menor, de trabalhadores da própria região. Estes trabalharam principalmente nas funçóes de auxiliares de escritório, subordinados diretamente aos chefes de setores (Luís Regueira Carneiro da Cunha Filho, 2016). Essa configuração nos permite afirmar que dentro do setor administrativo da fábrica existiu uma divisão regional e hierárquica do trabalho, onde se estabeleciam relaçóes de poder. Os funcionários vindos do Sudeste ocuparam os cargos de mais poder. Os assistentes do Nordeste ocuparam, a princípio, as funçóes de auxiliares. $\mathrm{Na}$ linha de montagem os operários eram da própria regiáo.

Flérida Cortizo disse que "a finalidade aqui foi tirar o pessoal da cana [...] foi botar o cortador de cana na indústria” (Flérida Cortizo Pozzas, 2016). Os operários eram qualificados dentro da fábrica. Esse processo contou com o treinamento oferecido por Arthur Sentieiro, mecânico especializado em manutenção, contratado pela Willys de São Bernardo em 1957 (Arthur Sentieiro, 2015). O treinamento dos novos operários ocorreu de fevereiro a julho de 1966.

O segundo ponto a ser destacado é quanto à estrutura de apoio oferecida pela Willys ao operário. A ala da enfermaria, o restaurante, condiçóes de acesso a boa moradia, ${ }^{10}$ o material escolar para os filhos dos operários eram, segundo relatos orais, oferecidos pela fábrica. Enquanto inúmeras crianças trabalhavam junto de suas famílias no corte da cana na zona da mata de Pernambuco, ${ }^{11}$ as

10 Importante destacarmos que não existiu uma vila fabril da Willys.

11 No Laboratório História e memória da UFPE e TRT $6^{\text {a }}$ região, é possível acessar inúmeros processos trabalhistas que envolvem crianças e menores de idade no trabalho de produção da cana-de-açúcar. 
crianças, filhos e filhas, dos operários da Willys podiam, de acordo com os relatos orais, ir à escola e ter material escolar novo todos os anos.

Ao estudar a fábrica de tecidos de Fernão Velho, localizada em Alagoas, entre os anos de 1943 e 1961, o historiador Marcelo Tavares Góes registrou algumas políticas de controle exercidas pela empresa. Essas políticas eram dirigidas no sentido de disciplinar a vida do seu operário e para assegurar a rentabilidade econômica da fábrica. A construção de "escolas, praça, coreto, ambulatório, de casas para os operários, entre outras açóes que despendiam muitos recursos financeiros e de poder" (Tavares, 2016, p. 30) da fábrica de tecidos, apontavam para essas políticas. Marcelo Góes afirma que todos esses elementos, de poder e controle, constituíram a cultura fabril de Fernão Velho e as crianças, filhas dos operários, vivenciaram-na. A convivência com os pais, o cotidiano escolar, os grupos de catequese e mesmo o grupo de escotismo, tudo era vigiado pelos patrôes. A vigilância sobre a vida dessas crianças se desdobrava num possível emprego anos mais tarde. "Seja mesmo na obediência e resistência ao que era considerado pelos patróes como bom costume em Fernão Velho. Elas, tão logo completassem 14 anos de idade, poderiam também trabalhar como operários" (Tavares, 2016, p. 30).

Nas pesquisas sobre a Willys encontramos poucos vestígios acerca dos filhos - crianças -, das mulheres ou da convivência familiar dos operários. Talvez por não haver existido uma vila fabril não se constituiu uma cultura fabril como em Fernão Velho. Contudo, desde a sua fase de construção em Pernambuco se tentou produzir a ideia da "fábrica como uma mãe" que acolhia e prestava assistência aos seus operários. As açóes dos dirigentes da fábrica registradas em jornais, revistas e nas lembranças e narrativas dos operários, permitem ler que essa narrativa foi uma estratégia de controle e de poder da Willys.

Essa ideia de uma "fábrica-mãe" para os trabalhadores e operários também foi discutida por Raquel Uchôa. A pesquisadora estudou a auto-gestáo dos trabalhadores na recuperação de fábricas falidas, movimento comum na década de 1990. O estudo é sobre a FACIT, uma fábrica localizada em Juiz de Fora (MG). Raquel Uchôa fez uma série de entrevistas com os operários e usou o termo "empresa-família" ao se referir ao suporte oferecido pela fábrica aos seus trabalhadores. Para a autora, "empresa-família" é uma referência, descrita pelos operários, à fábrica voltada para o trabalhador. Era um espaço de convivência e de sociabilidade. Era acolhedora e investia na qualificação e na relação com o trabalhador (Fernandes, 2012). Outro estudo que nos ajuda a pensar as estratégias adotadas pela Willys é o de Cecília Sardenberg. Para estudar as lembranças dos operários e das operárias da fábrica Plataforma, na Bahia, a pesquisadora fez uma série de entrevistas com esses atores sociais. Embora o foco do trabalho de 
Sardenberg não seja discutir a ideia de uma "fábrica-mãe", nos interessa observar como os seus entrevistados contam das relaçóes estabelecidas com a Plataforma. Uma das entrevistadas de Sardenberg disse que a fábrica era vista como uma mãe para os operários. A pesquisadora pontua que era comum ouvir relatos dos trabalhadores classificando a fábrica como uma grande família (Sardenberg, 1998).

Ao rememorar o cotidiano de trabalho e as sociabilidades, os operários da Willys deixaram o sorriso no rosto e as gesticulaçóes brandas. Seriam expressóes de gratidáo pelo trabalho e pelo acolhimento. Em nossa leitura, os operários se apresentaram como "trabalhadores" da Willys. Eles não diziam pertencer à classe trabalhadora ou operária. $\mathrm{O}$ sentimento de pertença estava relacionado à fábrica. Talvez as estratégias da Willys tenham sido eficazes em transformar a maneira de pensar e representar as relaçôes de poder e exploração vividas pelos seus operários.

Pensando em todas essas questóes sobre a fábrica, seus operários e as relações de trabalho, entendemos a importância de outros documentos para a construção dessa análise. Nesse caso, destacamos os registros dos processos trabalhistas impetrados na Junta de Conciliação e Julgamento (JCJ) de Jaboatão que possibilitam enveredar por outros caminhos e leituras. Distintos das trilhas oferecidas pelos relatos orais. Os operários tinham reclamaçóes recorrentes sobre o trabalho na fábrica. Foi nos documentos judiciais que localizamos as suas insatisfaçóes. Eram horas extras trabalhadas diariamente e não pagas. Reclamaçóes de avisos prévios e $13^{\circ}$ salários que também não foram pagos. Além disso, pedidos de indenizaçóes e de pagamentos de insalubridade foram registrados por operários. Diante de tantas reclamaçóes trabalhistas, não é possível amparar a ideia construída da "fábrica-mãe" para os seus operários como única narrativa. Apesar de não termos localizado registros de agitaçóes, motins, greves, reunióes, mobilizaçóes sindicais ou reivindicatórias de direitos trabalhistas que envolvessem os operários da Willys, encontramos nos processos trabalhistas as marcas das insatisfaçôes e do sistema de exploração da mão de obra.

Nesse sentido, é importante entendermos o cotidiano na fábrica, os mecanismos de disciplinamentos desses operários e o sistema de exploraçáo imposto pela Willys aos operários.

Frisamos que essas questóes são referentes à fábrica de Jaboatão. Quanto aos operários da Willys de São Bernardo do Campo, Antonio Luigi Negro (2004) diz que eram atuantes no sindicato, apresentaram reivindicaçóes e realizaram greves. As mobilizaçóes e lutas de trabalhadores e operários do Brasil na busca por seus direitos foram objeto de vários estudos. Desde a década de 1930, com a criação do Ministério do Trabalho, a luta dos operários se deu no sentido de legitimar e efetivar os direitos trabalhistas. Essas lutas foram vigiadas e, por diversas vezes, 
reprimidas pelo Estado brasileiro. ${ }^{12}$ No período privilegiado para estudo neste artigo a década de 1960 registrou diversas mobilizaçóes, "os trabalhadores foram a principal parcela da populaçáo alvo das perseguiçóes políticas e de diversas medidas tomadas pelo governo ditatorial militar, como ataques aos seus órgãos representativos, sistemáticas prisóes, torturas, execuçōes, desaparecimentos, bem como a implantaçáo de uma série de medidas que levaram ao arrocho salarial e à piora das condiçóes de trabalho" (São Paulo, 2015), como destaca o relatório da Comissão da Verdade do Estado de São Paulo "Rubens Paiva", ao discutir a perseguição aos trabalhadores urbanos e ao movimento operário. Após o golpe militar de 64, esses movimentos foram postos na ilegalidade e seus líderes perseguidos. Entretanto, a luta pela garantia dos direitos continuava.

Ainda pensando a década de 1960, o ano de 1968 foi emblemático na organização dos operários do Brasil. As greves eclodiram em várias partes do país. Em 17 de julho daquele ano, o Correio da Manhã (RJ) noticiou a ocupação de seis fábricas, em Osasco (SP), por quase cinco mil operários. Uma dessas, era a Companhia Brasileira de Materiais Ferroviários (Cobrasma). Segundo o jornal, 1.732 operários da fábrica "mantiveram presos 16 engenheiros e 50 funcionários da administração, exigiam, em greve, aumento salarial de $35 \%$, contrato coletivo de dois anos, aumentos periódicos e melhores condiçóes de segurança e salubridade no trabalho" (SP: Operários..., 1968). Segundo a matéria de capa do jornal, o delegado regional do trabalho - general Moacyr Gaia - considerou a greve ilegal e enviou até a fábrica pelotóes de choque, agentes do Departamento de Ordem Política e Social (DOPS) e da Polícia Federal. O delegado considerou um ato de desordem e de subversão dos operários. Dias depois, o jornal voltou a noticiar a greve na Cobrasma. Parte da fábrica havia voltado a funcionar, entretanto uma parte importante continuava em greve: a funilaria. Prisóes de operários e líderes sindicais foram efetuadas (Osasco..., 1968). No dia 27 do mesmo mês, o discurso de Frederico Brandão, líder sindical, foi publicado no Correio da Manhã (RJ). Sobre a greve da Cobrasma destacou que "paga um salário de miséria e não dá condições de trabalho. Contra isso, fizemos uma greve organizada, ordeira e por isso fomos reprimidos pela Polícia que espancou a gente sem piedade, deixando vários operários feridos e acamados até hoje” (Regime..., 1968). O discurso do líder sindical registrava a denúncia da repressão sofrida pelos operários na luta por seus direitos.

$\mathrm{Na}$ região do $\mathrm{ABC}$ paulista, outras tantas fábricas - "Lonaflex, Fósforo Granada, Braseixos, Lâmpadas Osram e Metalúrgicas Keller” (Correio da Manhã

\footnotetext{
12 Para saber mais, ver Memórias da Ditadura. Disponível em: $<$ http://memoriasdaditadura.org.br/ operarios/>. Acesso em: 14 dez. 2020.
} 
$(R J, 1968)$ - também aderiram às greves contra o arrocho salarial imposto pelos militares e pela busca de melhores condiçóes de trabalho e salário. Assim como os operários da Willys Overland de São Bernardo do Campo. Para o historiador Antonio Luigi Negro, "as mediçôes de forças, que as greves dos metalúrgicos de Contagem, ABC e Osasco promoveram no primeiro semestre de 1968" (Negro, 2004, p. 297), reanimaram o movimento sindical, trazendo-o de volta ao cenário político, "ressurgindo algumas corajosas paralisaçóes ao longo do ano" (Negro, 2004, p. 297). O historiador Ari Couto diz que as lutas operárias marcaram os últimos anos da década de 1960 no país (Couto, 2001).

Em 1968, as agitaçóes sociais dos trabalhadores rurais em Pernambuco também eram de conhecimento das autoridades políticas e policiais do país. A historiadora Camila Melo estudou a greve organizada pelos trabalhadores rurais do Cabo de Santo Agostinho (Melo, 2018). Entretanto, no município vizinho, Jaboatão, nenhuma mobilização dos operários da Willys foi registrada.

Nos relatos orais, os operários e funcionários da administração da Willys Jaboatão foram categóricos ao dizer que na fábrica os "trabalhadores" eram "disciplinados". Ainda segundo esses relatos, não houve greve e nem atuação das organizações sindicais. A funcionária da Ford-Willys, Aparecida, lembrou: "os funcionários, quando havia greve de metalúrgico aqui em Pernambuco, os funcionários da Ford brigavam com o sindicato na porta que era para entrar, porque eles pagavam direitinho, a Ford era uma mãe, então eles brigavam realmente com o pessoal do sindicato para entrar, teve uma vez que teve até tiro, porque o sindicato queria segurar a gente de todo o jeito, e todo mundo entrou para trabalhar" (José Matias de Lima Filho, 2016). Aparecida se referia, provavelmente, às greves em outras fábricas nas quais o sindicato dos metalúrgicos intervinha e ao tentar a adesão dos trabalhadores da Willys-Ford foram barrados. ${ }^{13}$ O Diario de Pernambuco registrou uma mobilização de greve dos metalúrgicos em Pernambuco no ano de 1979. A reclamação dos operários era por aumento salarial. Reclamava-se que os empresários conseguiram lucros exorbitantes e os operários recebiam salários miseráveis, muito abaixo do que julgavam ser um salário digno.

13 Estudos apontam que entre 1964 e 1978, a organização sindical dos operários em Pernambuco foi esvaziada pela repressão do governo militar. Nesse período, os sindicatos atuaram em funções burocráticas, como a homologação de rescisões contratuais. No final da década de 1970, registrou-se uma reorganização e novas mobilizações dos operários, com destaque para o sindicato dos metalúrgicos de Pernambuco. Para uma discussão aprofundada sobre o chamado "novo sindicalismo" em Pernambuco e a retomada das greves dos operários ver: ARAÚJO, Suzane Batista de. "Temos que de novo ser donos da nossa casa": a (re) organização e atuação do Sindicato dos Metalúrgicos em Pernambuco 1978-1985. Dissertação (Mestrado em História) - UFPE, Recife, PE, 2019; FERREIRA, Rafael Leite. O "novo sindicalismo" urbano em Pernambuco (1979-1984): entre mudanças e permanências. Dissertação (Mestrado em História) - UFPE, Recife, PE, 2012. 
No anúncio da possível greve, o jornal dizia que "para complicar mais ainda a situação, muitas indústrias metalúrgicas começaram a dispensar empregados e só a Caio Norte demitiu 190, cujas homologaçóes estão sendo feitas no sindicato" (Metalúrgico..., 1979).

\section{Considerações finais}

A memória construída pelos operários da fábrica Willys de Jaboatão apontam para um local de trabalho acolhedor, com dirigentes dedicados ao bem estar dos seus empregados e de suas famílias. Não havia motivo para reivindicaçóes. $\mathrm{O}$ trabalho era desenvolvido com segurança e os operários estavam satisfeitos. Entretanto, o cruzamento de fontes nos permitiu outras leituras para além da Willys como uma fábrica-mãe para os seus operários. As estratégias de exploração e disciplinamentos adotados pela Willys não silenciaram os operários. As suas lutas por melhores condiçóes de trabalho foram registradas na arena da Justiça do Trabalho e foram analisadas a partir dos processos trabalhistas impetrados na JCJ de Jaboatão. A ausência de greves, paralisaçóes e reuniôes sindicais não anularam as mobilizaçóes desses operários na busca pela efetivação dos seus direitos. A memória afetiva construída por alguns operários da fábrica, a disciplina de trabalho diante das estratégias de exploração e até mesmo a apatia diante das tramas políticas não encerraram as discussóes e leituras sobre o cotidiano fabril.

\section{Referências}

COUTO, Ari Marcelo Macedo. Ao soar do apito a greve comę̧ou Cobrasma: lutas e resistências (1962-1968). Dissertação (Mestrado em História) - PUC, São Paulo, SP, 2001.

FERNANDES, Raquel de Araújo Uchôa. Entre o chão e a gestão da fábrica: as trajetórias dos trabalhadores da FACIT. Tese (Doutorado em Ciências Sociais) - UERJ, Rio de Janeiro, RJ, 2012.

GUIMARÁES NETO, Regina Beatriz. Cidades da mineração, memória e práticas culturais. Mato Grosso na primeira metade do século XX. Cuiabá: EdUFMT. 2006.

MELO, Camila Maria de Araújo. Entre dois senhores: o patrão e a fome - as greves dos trabalhadores rurais no cabo de Santo Agostinho - PE, 1966-1968. Dissertação (Mestrado em História) - UFPE, Recife, PE, 2018. 
MONTENEGRO, Antonio Torres. Studebaker, Delco, Guide, General Motors na fala dos operários. Revista CLIO-Série História do Nordeste, Recife, v. 15, n. 1, p. 19-37, 1994.

NEGRO, Antonio Luigi. Linhas de Montagem: o industrialismo nacionaldesenvolvimentista e a sindicalização dos trabalhadores (1945-1978). São Paulo: Boitempo, 2004.

SARDENBERG, Cecilia Maria Bacellar. O gênero da memória: lembranças de operários e lembranças de operárias In: PASSOS, Elizete Silva; ALVES, Ivia Iracema Duarte; MACÊDO, Márcia (Org.). Metamorfoses: Gênero na Perspectiva Interdisciplinar. Salvador: NEIM/UFBA, 1998. (Coleção Bahianas, v. 3).

METALÚRGICO pronto para greve depende só da reunião de hoje. Diário de Pernambuco, Recife, p. A6, 6 set. 1979.

OSASCO não pára greve e mais cinco são presos. Correio da Manhã, Rio de Janeiro, 23 jul. 1968.

REGIME totalitário. Correio da Manhã, Rio de Janeiro, 27 jul. 1968.

SÃO PAUlO (Estado). Comissão da Verdade do Estado de São Paulo "Rubens Paiva". Relatório. Tomo I - Parte II - A perseguição aos trabalhadores urbanos e o movimento operário. São Paulo: Assembleia Legislativa 2015. Disponível em:< http:// comissaodaverdade.al.sp.gov.br/relatorio/>. Acesso em: 14 dez. 2020.

SILVA, Diego Carvalho da. Partidos e alianças politicas na "Moscouzinho do Brasil": os comunistas e as eleiçóes municipais de outubro de 1947 em Jaboatáo-PE. Rio de Janeiro: 7 letras, 2017.

SP: OPERÁRIOS ocupam 6 fábricas e são desalojados pela polícia. Correio da Manhã, Rio de Janeiro, capa, 17 jul. 1968.

TAVARES, Marcelo Góes. Do tecer da memória ao tecido da história: Operários, trabalho e política na indústria têxtil em Fernão Velho (Maceió, AL, 1943-1961). Tese (Doutorado em História) - UFPE, Recife, PE, 2016.

VÊM de longe. Revista Quatro Rodas, São Paulo, n. x, p. 47, 1966.

\section{Fontes orais}

BARBOSA, Antonio Justolino [mar. 2018]. Entrevistadora: Karlene Araújo. Jaboatão dos Guararapes, PE, 27 mar. 2018. 
CUNHA FILHO, Luís Regueira Carneiro da [74 anos]. [mai. 2016]. Entrevistadora: Karlene Araújo. Jaboatão dos Guararapes, PE, 18 mai. 2016.

LIMA FILHO, José Matias de [set. 2016]. Entrevistador: Karlene Araújo. Paulista, PE, 15 set. 2016.

POZZAS, Flérida Cortizo [82 anos]. [jul. 2016]. Entrevistadora: Karlene Araújo. Jaboatão dos Guararapes, PE, 8 jul. 2016.

SENTIEIRO, Arthur [jun. 2015]. Entrevistadora: Karlene Araújo. Encaminhada por e-mail, 16 jun. 2015.

Resumo: A fábrica norte americana Willys Overland construiu uma filial em Jaboatâo (PE) em 1966. Homens e mulheres sem experiência de trabalho fabril foram empregados e a qualificação da mão de obra foi realizada dentro da fábrica. Este artigo analisa os relatos de memória dos operários da Willys de Jaboatão e a construção da ideia de uma fábrica-mãe para os seus operários. Nesses relatos de memória, a Willys ganhou a forma de uma fábrica acolhedora, atenta às demandas dos seus trabalhadores. Lembrada por açōes assistencialistas e pelo fácil cotidiano de trabalho. Os discursos propagados pelos dirigentes da fábrica referemse a um operário feliz e satisfeito, que nada tinha de reclamar. Entretanto, o diálogo com outros documentos, como processos trabalhistas, nos permite identificar as estratégias de exploraçáo, disciplina e silenciamento adotadas pela Willys.

Palavras-chave: Memória. Operários. Trabalho. Fábrica.

\title{
The mother factory: factory daily life and the construction of the memory of Willys Overland Workers in Jaboatáo
}

\begin{abstract}
The North American factory Willys Overland built a branch in Jaboatăo (PE) in 1966. Men and women with no experience in manufacturing work were employed and the qualification of labor was carried out inside the factory. This article analyzes the memory reports of Willys de Jaboatáo workers and the construction of the idea of a "mother factory" for their workers. In these reports of memory, Willys took the form of a welcoming factory, attentive to the demands of its workers. Remembered for assistance actions and for the easy daily work. The speeches propagated by the factory managers refer to a happy and satisfied worker, that he had nothing to complain about. However, dialogue with other documents, such as labor lawsuits, allows us to identify the exploration, discipline and silencing strategies adopted by Willys.
\end{abstract}

Keywords: Memory. Workers. Labor. Factory.

Recebido em 24/08/20

Aprovado em 21/10/20 